\title{
MASS TREATMENT FOR INTESTINAL HELMINTHIASIS CONTROL IN AN AMAZONIAN ENDEMIC AREA IN BRAZIL
}

\begin{abstract}
Márcio Neves BÓIA(1,4), Filipe Anibal CARVALHO-COSTA(2), Fernando Campos SODRÉ(3), Walter A. EYER-SILVA(2), Cristiane Cruz LAMAS(2), Marcelo Rosadinski LYRA(2), Vitor Laerte PINTO JÚNIOR(2), João Paulo CANTALICE FILHO(2), Ana Lucia L. OLIVEIRA(2), Liège M. Abreu CARVALHO(2), Julise B. GROSS(2), Ana Lucia S. SOUZA(2), Teruo Ito de MORAES(2), Elkin Hernán BERMUDEZ-AZA(2), Ezequias Baptista MARTINS(2) \& José Rodrigues COURA(1)
\end{abstract}

\section{SUMMARY}

The objective of the present study was to estimate the prevalence of soil-transmitted helminthiasis and evaluate the sanitary conditions and the role of a mass treatment campaign for control of these infections in Santa Isabel do Rio Negro. A crosssectional survey was carried out in 2002, to obtain data related to the sanitary conditions of the population and fecal samples for parasitological examination in 308 individuals, followed by a mass treatment with albendazole or mebendazole with coverage of $83 \%$ of the city population in 2003. A new survey was carried out in 2004, involving 214 individuals, for comparison of the prevalences of intestinal parasitosis before and after the mass treatment. The prevalences of ascariasis, trichuriasis and hookworm infection were $48 \% ; 27 \%$ and $21 \%$ respectively in 2002. There was a significant decrease for the frequency of infections by Ascaris lumbricoides $(\mathrm{p}<0.05 ; \mathrm{OR} / 95 \% \mathrm{CI}=0.44 / 0.30-0.65)$, Trichuris trichiura $(\mathrm{p}<0.05 ; \mathrm{OR} / 95 \% \mathrm{CI}=0.37 / 0.22-0.62)$, hookworm $(\mathrm{p}<0.05$; OR / 95\% CI = $0.03 / 0.01-0.15)$ and helminth poliparasitism $(\mathrm{p}<0.05$; OR / 95\% CI = $0.16 / 0.08-0.32)$. It was also noticed a decrease of prevalence of infection by Entamoeba histolytica / dispar $(\mathrm{p}<0.05 ; \mathrm{OR} / 95 \% \mathrm{CI}=0.30 / 0.19-$ 0.49 ) and non-pathogenic amoebas. It was inferred that a mass treatment can contribute to the control of soil-transmitted helminthiasis as a practicable short-dated measure. However, governmental plans for public health, education and urban infrastructure are essential for the sustained reduction of prevalences of those infections.

KEYWORDS: Intestinal helminthiasis; Mass Treatment; Control; Amazon.

\section{INTRODUCTION}

Intestinal parasitosis lie among the many health problems observed in economically disadvantaged populations of developing countries.

Those infections reveal clear social and economical determinants, with high prevalences in regions with deficiency in sanitation, potable water supplies, education and adequate dwelling conditions $\mathrm{s}^{30}$.

The burden attributed to soil-transmitted helminthiasis has been studied in three domains: growth and ponderous gain deficits, iron deficiency anemia and disturbances of cognitive function ${ }^{5,30}$.

The association between malnutrition and intestinal parasitosis has been demonstrated in cross-sectional surveys involving the correlation between anthropometric data and both prevalence and intensity of infections ${ }^{15,24,26,27,29}$. Those conditions cause clear damage to full individual development, affecting even cognitive function and school performance of children ${ }^{5,25}$.
Besides those insidious course effects, acute complications occur, often serious and potentially fatal, such as intestinal obstruction, intense anemia and rectal prolapse ${ }^{8}$, observed mainly when occurring infections by high parasitic loads, afforded by high levels of exposition observed in absence of adequate conditions of sanitation and dejection destination.

From 2000 on, the World Health Organization (WHO) has been working up control strategies against soil-transmitted helminthiasis, intensely based on mass administration of anti-helmintics ${ }^{36,37}$.

Those strategies are based mainly on safety and costs of the drugs used, supervising systems, maintenance of actions and community participation $^{14,21,22,32}$.

Mass administration of anti-helmintics is considered strategic and particularly effective in the control of hookworm infection and ascaridiasis $^{4,10}$. In areas of high prevalence of infection by Trichuris trichiura the benefits would be focused on reduction of prevalence and decreasing of parasitical burden, with preventions of severe forms ${ }^{10}$. 


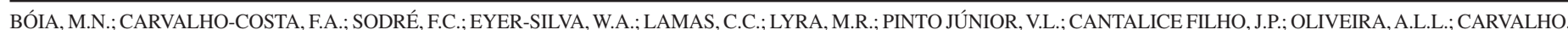
L.M.A.; GROSS, J.B.; SOUZA, A.L.S.; MORAES, T.I.; BERMUDEZ-AZA, E.H.; MARTINS, E.B. \& COURA, J.R. - Mass treatment for intestinal helminthiasis control in an Amazonian endemic area in Brazil. Rev. Inst. Med. trop. S. Paulo, 48(4): 189-195, 2006.

Mass administration of anti-helmintics has been performed in some countries and has used benzimidazole derivatives as choice drugs, including albendazole and mebendazole $\mathrm{e}^{11,23,31,38}$. These drugs act through inhibition of tubulin-polimerase, impeding the formation of microtubules and cellular division ${ }^{19}$, admitting its administration to one year older children ${ }^{21,22}$. Experimental studies involving the administration of mebendazole and albendazole to rats and rabbits showed teratogenic potential for both drugs only in high doses ${ }^{33,35}$. The risk of occurrence of congenital abnormalities associated to the administration of benzimidazolics during pregnancy was analyzed by BRADLEY \& HORTON ${ }^{2}$ and DE SILVA et al. ${ }^{9}$. Those authors suggested that the treatment must be avoided during the first trimester of pregnancy.

Except for the special program for schistosomiasis control, which had as main axis the administration of oxamniquine and praziquantel in endemic areas, in 70's years ${ }^{6,18}$ there is no accumulated experience in mass treatments with anti-helmintics in Brazil.

The objective of this survey was, in the first stage (2002), to characterize medical and sanitary conditions of the studied area, and estimate the prevalence of intestinal parasitosis. In a second stage it was aimed carry out a mass treatment campaign for the main intestinal helminthiasis, and to evaluate its possible effect on prevalence, comparing two coproparasitologic surveys performed in 2002 and 2004.

\section{METHODS}

Studied area and population: The municipality of Santa Isabel do Rio Negro is situated in the northwest of Amazonas State $\left(0^{\circ} 28^{\prime} \mathrm{S}\right.$ and $65^{\circ} 32^{\prime} \mathrm{W}$ ), being distant $781 \mathrm{~km}$ from Manaus, capital of the State, through the Negro river. Localized in the region of Alto Rio Negro, it occupies an area of $62,846 \mathrm{~km}^{2}, 90 \%$ of which being covered by the Amazonian Rain Forest. The weather is hot and humid, with temperatures between 26 e $32{ }^{\circ} \mathrm{C}^{16}$.

The population of 10,561 inhabitants has indigenous ancestry in its majority, being 4,220 of them residents at the municipality's seat and 6,341 distributed in riverine communities over the municipality territory, including part of the Yanomami Indigenous Land ${ }^{16}$. Inhabitants of the municipality seat are descendants from Tukano Oriental (which includes Tukano, Pira-tapuya and Desana groups) and Aruak (Baniwa, Bare and Tariana groups) speaking societies. At present, interethnic marriage is very frequent, being common the existence of individuals with parents belonging to different groups.

The health system is extremely deficient and the municipality does not have regular medical assistence. There is no policy for intestinal parasitosis control in the region.

Negro river has dark and very acid water (with $\mathrm{pH}$ about 4), owing to the great amount of organic materials in decomposition produced by the forest what causes problems to the population's potable water supplying system ${ }^{17}$. The supplying of drinking water is promoted by the Sanitation Company of Amazonas State (COSAMA), through direct suction from the Negro river. The suction is made too closely to the margin, in an area attended by laundresses and contaminated by dejections coming from neighborhoods of the municipality's seat, of which margins flood in the high-tide period. The water is conveyed to the population after being roughly treated with sodium hypochlorite, without filtration and decantation stages, maintaining its dark color and acid $\mathrm{pH}$. The dwellers do not ingest this water, owing to its bad taste; smell and final aspect, preferring for consume the water from artesian wells, not close to their residences. Sanitary infrastructure is deficient and there is no system for excreta collection.

This survey involved the urban population of the municipality's seat.

Collecting and processing of fecal samples and demographic data: A cross-sectional survey was performed in July 2002, involving collection of fecal samples and obtainment, through a questionnaire, of data related to demographic, socioeconomic and sanitary conditions, in 87 of the 773 domiciles of the municipality's seat. The technique of systematic sampling by conglomerate was employed, being defined the domicile as sample unity. Variables related to the parents, such as literacy rate and income were extrapolated to the whole family in order to compare frequencies of soil-transmitted helminthiasis infection between groups. The domiciles were visited by post graduation students of the Department of Tropical Medicine of the Oswaldo Cruz Foundation, who provided plastic fecal collectors with preservative ( $10 \%$ formaldehyde) for 474 people. Of those, 308 returned the fecal sample. In July 2004, a new survey was performed in the municipality's seat, using the same methodology of sampling and collecting of fecal samples. The fecal samples were returned by 214 individuals in this survey. The samples in 2002 and 2004 were examined at the locality, by the same parasitologists in both years, through the technique of Coprotest $^{\circledR}$, a commercial kit, modified from Ritchie method ${ }^{39}$ and no additional quality control measures were taken.

The mass treatment: In July 2003 was performed in the city a mass treatment for intestinal helminthiasis. Physicians of the Oswaldo Cruz Foundation visited, during two weeks, every occupied domicile of the city, administrating under supervision, one $400 \mathrm{mg}$ single dose of albendazole for every individual with more than 24 months of age and prescribing a treatment with mebendazole for children aged between 12 and 24 months, with two daily doses of $100 \mathrm{mg}$ administered during three days. Pregnant women and those with amenorrhea were excluded of the survey.

We administered 3,381 single doses of albendazole and 118 treatments with mebendazole, reaching coverage of about $83 \%$ of the population.

Analisys methods: Data were analyzed through descriptive statistics of the sample as a whole and stratified by age. Comparison of frequencies of categorical variables was performed through bivariate analysis by the chi-square test, considering statistical significance at the level of 5\%. Data were analyzed and stored on EpiInfo version 3.2.2.

ETHICS: Every family involved in the survey was included after the responsible having signed an informed consent form, being the protocol of research approved by the Oswaldo Cruz Foundation Committee for Ethics on Research. 


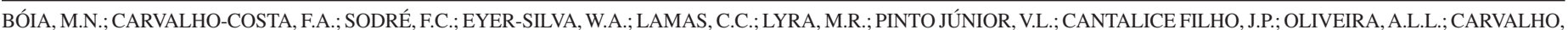

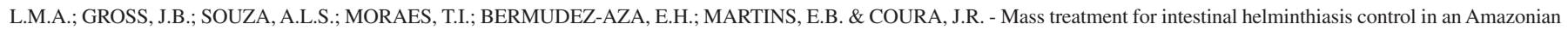
endemic area in Brazil. Rev. Inst. Med. trop. S. Paulo, 48(4): 189-195, 2006.

\section{RESULTS}

The 2002 survey showed that the majority of adult population $(56 \%$, $79 / 141$ ) has four or less education years, with an illiteracy rate of $17 \%$. It was observed that $26 \%(23 / 87)$ of the dwellings had no latrines, $30 \%(26 / 87)$ had rude outdoor ones, with no feaces tanks; and $66 \%$ (57/87) had potable water supply (canalized or supplied by wells). Monthly income of $68 \%(96 / 141)$ of surveyed adults is until two minimum wages (Table 1).

Table 2 shows that families with no cash-oriented activities presented a higher frequency of $A$. lumbricoides infection (57\%) than those with a monthly income of at least three minimum wages $(30 \%$, $\mathrm{p}<0.05)$. Also, ascariasis and hookworm infection were more frequent in people living in dwellings without latrines (59\% and $30 \%$ respectively, $\mathrm{p}<0.05$ for both). Considering any infection by the three major soil-transmitted helminths studied (A. lumbricoides, T. trichiura and hookworm), we observed higher frequencies on groups does not possessing latrine or cash-oriented activities $(67 \%$ and $73 \%$,

\section{Table 1}

Socioeconomic and educational data of 141 adults and characteristics of 87 dwellings surveyed in Santa Isabel do Rio Negro, 2002

\begin{tabular}{|c|c|c|}
\hline \multirow{2}{*}{$\begin{array}{l}\text { Variable } \\
\text { Literacy rate } *(\text { education years })\end{array}$} & \multicolumn{2}{|c|}{ Frequency } \\
\hline & $N$ & $\%$ \\
\hline \multicolumn{3}{|l|}{ Males $\mathrm{n}=53(38 \%)$} \\
\hline Illiterate & 9 & 17 \\
\hline 1 to 4 & 23 & 43 \\
\hline$\geq 5$ & 21 & 40 \\
\hline \multicolumn{3}{|l|}{ Females $\mathrm{n}=88(62 \%)$} \\
\hline Illiterate & 14 & 16 \\
\hline 1 to 4 & 33 & 37 \\
\hline$\geq 5$ & 41 & 47 \\
\hline \multicolumn{3}{|l|}{ Dwelling characteristics } \\
\hline \multicolumn{3}{|l|}{ Floor } \\
\hline Wood & 7 & 8 \\
\hline Cement & 58 & 67 \\
\hline Ceramic & 12 & 13 \\
\hline Soil & 5 & 6 \\
\hline Other & 5 & 6 \\
\hline \multicolumn{3}{|l|}{ Latrine } \\
\hline Inexistent & 23 & 26 \\
\hline Indoor (with rudimentary tank) & 26 & 30 \\
\hline Outdoor (with no tank) & 38 & 44 \\
\hline \multicolumn{3}{|l|}{ Source of drinking water } \\
\hline Canalized & 42 & 48 \\
\hline Well & 15 & 18 \\
\hline Rain & 2 & 2 \\
\hline River & 8 & 9 \\
\hline Other & 20 & 23 \\
\hline \multicolumn{3}{|l|}{ Income } \\
\hline No cash-oriented activities & 6 & 4 \\
\hline 1 to 2 minimum wages* & 90 & 64 \\
\hline Up to 3 minimum wages* & 45 & 32 \\
\hline
\end{tabular}

*1 minimum wage $=150$ USD monthly respectively) when compared to groups with indoor latrines or monthly income up to three minimum wages (49\% and $60 \%$ respectively, $\mathrm{p}<$ 0.05 for both).

The comparison of helminths and protozoa prevalences between the years 2002 and 2004 is presented in Tables 3 and 4. We observed statistically significant falls for Ascaris lumbricoides, Trichuris trichiura, hookworm, Entamoeba histolytica/dispar, Entamoeba coli and Iodamoeba butschlii. The cestoid Hymenolepis nana was detected in five subjects in 2002 and no cases of this parasite were found in 2004. Frequency of poliparasitism was also reduced as showed on Table 5. The survey carried out in 2002 showed that $26.5 \%$ of population was infected with two or more helminths. This frequency was $5.6 \%$ in the 2004 survey.

\section{DISCUSSION}

There is little experience in Brazil with the mass administration of anti-helmintics for soil-transmitted helminthiasis control. This kind of intervention has been recommended by WHO, as related in the Experts Committee's Report ${ }^{37}$.

Our comparison of intestinal parasitosis prevalences in the years 2002 and 2004 showed significant reduction for Ascaris lumbricoides, Trichuris trichiura and hookworms, evidencing also significant reduction of frequencies of infection by Entamoeba histolytica/dispar and other amoebas. Though the administration of a single dose of albendazole is not recommended for treatment of amebiasis, GELTMAN et al. ${ }^{12}$ refer statistically significant decrease of Entamoeba histolytica/dispar infection prevalence in African refugees who migrated to the United States after pre-departure administration of a $400 \mathrm{mg}$ single dose of this drug. The authors compared two surveys, performed before and after the implementation of a program of empiric administration of albendazole before the individuals' departure from their countries of origin ${ }^{12}$. Although we have observed similar results, additional surveys must be performed to evaluate the impact, at public health level, of the treatment with a single dose of albendazole in infections by Entamoeba histolytica/dispar and non-pathogenic amoebas.

Although reduction in intensity of infections was not assessed in the present study, it could be assumed that the fall of prevalence of soil-transmitted helminthiasis might have led to an additional reduction of the disease burden associated to these infections ${ }^{13}$.

It has been emphasized that school age children have the risk of developing chronic complications associated to intestinal helmintiasis ${ }^{3,7}$. The 1993 World Development Report considered intestinal helminths as a first cause of disease burden in children aged 5 - 14 years $^{34}$. The conditions associated to those infections include growth retardation, reduced physical activity, anemia and impaired educational performance ${ }^{30}$. Girls and women are also considered as vulnerable groups to those complications, mainly related to the development of iron deficiency, having being related that $56 \%$ of pregnant women in underdeveloped countries have anemia ${ }^{1}$.

High prevalences of intestinal parasitosis at Santa Isabel do Rio Negro observed on 2002's survey reveal clear socioambiental 


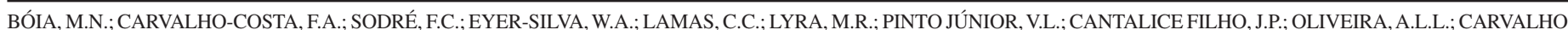
L.M.A.; GROSS, J.B.; SOUZA, A.L.S.; MORAES, T.I.; BERMUDEZ-AZA, E.H.; MARTINS, E.B. \& COURA, J.R. - Mass treatment for intestinal helminthiasis control in an Amazonian endemic area in Brazil. Rev. Inst. Med. trop. S. Paulo, 48(4): 189-195, 2006.

Table 2

Frequency of soil-transmitted helminthiasis according to some socioeconomic variables in Santa Isabel do Rio Negro, 2002 (*Parental data were extrapolated to the whole family)

\begin{tabular}{|c|c|c|c|c|c|c|c|c|}
\hline \multirow[t]{2}{*}{ Variable } & \multicolumn{2}{|c|}{$\begin{array}{l}\text { Ascaris } \\
\text { lumbricoides }\end{array}$} & \multicolumn{2}{|c|}{$\begin{array}{l}\text { Trichuris } \\
\text { trichiura }\end{array}$} & \multicolumn{2}{|c|}{ Hookworm } & \multicolumn{2}{|c|}{$\begin{array}{l}\text { Any helminth } \\
\text { parasitism }\end{array}$} \\
\hline & $\%$ & $\begin{array}{c}\mathrm{p} \\
\text { (chi-square } \\
\text { for trend) }\end{array}$ & $\%$ & $\begin{array}{c}\mathrm{p} \\
\text { (chi-square } \\
\text { for trend) }\end{array}$ & $\%$ & $\begin{array}{c}\mathrm{p} \\
\text { (chi-square } \\
\text { for trend) }\end{array}$ & $\%$ & $\begin{array}{c}\mathrm{p} \\
\text { (chi-square } \\
\text { for trend) }\end{array}$ \\
\hline \multicolumn{9}{|l|}{ Education* (years on school) } \\
\hline none $\mathrm{n}=41$ & 61 & 0.18 & 19 & 0.27 & 29 & 0.09 & 71 & 0.40 \\
\hline One to four $\mathrm{n}=118$ & 45 & & 22 & & 16 & & 59 & \\
\hline Five or more $n=136$ & 46 & & 29 & & 26 & & 64 & \\
\hline \multicolumn{9}{|l|}{ Family income* (minimum wages) } \\
\hline No cash-oriented activities $n=21$ & 57 & $<0.05$ & 19 & 0.32 & 33 & 0.10 & 67 & $<0.05$ \\
\hline One to two $n=193$ & 55 & & 28 & & 23 & & 69 & \\
\hline Three or more $\mathrm{n}=94$ & 30 & & 21 & & 15 & & 49 & \\
\hline \multicolumn{9}{|l|}{ Latrine } \\
\hline Inexistent $\mathrm{n}=92$ & 59 & $<0.05$ & 30 & 0.72 & 30 & $<0.05$ & 73 & $<0.05$ \\
\hline Inside the house (with rudimentary tank) $n=75$ & 41 & & 24 & & 15 & & 55 & \\
\hline Outside the house (with no tank) $\mathrm{n}=131$ & 43 & & 26 & & 20 & & 60 & \\
\hline
\end{tabular}

Table 3

Comparison of soil-transmitted helminth infections frequencies in 2002 and 2004 in Santa Isabel do Rio Negro, Amazonas, Brazil

\begin{tabular}{|c|c|c|c|c|c|c|c|c|c|c|c|c|c|c|c|c|}
\hline \multirow{2}{*}{$\frac{\text { Age group (years) }}{\text { Parasite }}$} & \multicolumn{4}{|c|}{1 to 5} & \multicolumn{4}{|c|}{6 to 14} & \multicolumn{4}{|c|}{$>14$} & \multicolumn{4}{|c|}{ Total } \\
\hline & $\begin{array}{c}2002 \\
\mathrm{n}=71\end{array}$ & $\begin{array}{c}2004 \\
\mathrm{n}=40\end{array}$ & $\begin{array}{c}\text { OR } \\
95 \% \mathrm{CI}\end{array}$ & $\mathrm{p}$ & $\begin{array}{c}2002 \\
\mathrm{n}=86\end{array}$ & $\begin{array}{c}2004 \\
\mathrm{n}=54\end{array}$ & $\begin{array}{c}\mathrm{OR} \\
95 \% \mathrm{CI}\end{array}$ & $\mathrm{p}$ & $\begin{array}{c}2002 \\
\mathrm{n}=151\end{array}$ & $\begin{array}{c}2004 \\
\mathrm{n}=119\end{array}$ & $\begin{array}{c}\text { OR } \\
95 \% \mathrm{CI}\end{array}$ & $\mathrm{p}$ & $\begin{array}{c}2002 \\
\mathrm{n}=308\end{array}$ & $\begin{array}{c}2004 \\
\mathrm{n}=213\end{array}$ & $\begin{array}{c}\text { OR } \\
95 \% \mathrm{CI}\end{array}$ & $\mathrm{p}$ \\
\hline $\begin{array}{l}\text { Any helminth } \\
\mathrm{n}(\%)\end{array}$ & $\begin{array}{c}41 \\
(58)\end{array}$ & $\begin{array}{c}7 \\
(18)\end{array}$ & $\begin{array}{c}0.16 \\
(0.05-0.43)\end{array}$ & $<0.05$ & $\begin{array}{l}56 \\
(65)\end{array}$ & $\begin{array}{l}23 \\
(43)\end{array}$ & $\begin{array}{c}0.40 \\
(0.19-0.85)\end{array}$ & $<0.05$ & $\begin{array}{c}97 \\
(64)\end{array}$ & $\begin{array}{l}31 \\
(26)\end{array}$ & $\begin{array}{c}0.20 \\
(0.11-0.34)\end{array}$ & $<0.05$ & $\begin{array}{l}194 \\
(63)\end{array}$ & $\begin{array}{c}61 \\
(29)\end{array}$ & $\begin{array}{c}0.24 \\
(0.16-0.35)\end{array}$ & $<0.05$ \\
\hline $\begin{array}{l}\text { Ascaris lumbricoides } \\
\mathrm{n}(\%)\end{array}$ & $\begin{array}{c}34 \\
(48)\end{array}$ & $\begin{array}{c}7 \\
(18)\end{array}$ & $\begin{array}{c}0.23 \\
(0.08-0.64)\end{array}$ & $<0.05$ & $\begin{array}{c}44 \\
(51)\end{array}$ & $\begin{array}{c}23 \\
(43)\end{array}$ & $\begin{array}{c}0.71 \\
(0.34-1.49)\end{array}$ & 0.32 & $\begin{array}{c}69 \\
(47)\end{array}$ & $\begin{array}{c}31 \\
(26)\end{array}$ & $\begin{array}{c}0.42 \\
(0.24-0.73)\end{array}$ & $<0.05$ & $\begin{array}{l}147 \\
(48)\end{array}$ & $\begin{array}{l}61 \\
(29)\end{array}$ & $\begin{array}{c}0.44 \\
(0.30-0.65)\end{array}$ & $<0.05$ \\
\hline $\begin{array}{l}\text { Trichuris trichiura } \\
\mathrm{n}(\%)\end{array}$ & $\begin{array}{c}12 \\
(17)\end{array}$ & $\begin{array}{c}4 \\
(10)\end{array}$ & $\begin{array}{c}0.55 \\
(0.14-2.02)\end{array}$ & 0.32 & $\begin{array}{l}24 \\
(28)\end{array}$ & $\begin{array}{c}9 \\
(17)\end{array}$ & $\begin{array}{c}0.52 \\
(0.20-1.31)\end{array}$ & 0.12 & $\begin{array}{l}43 \\
(28)\end{array}$ & $\begin{array}{c}11 \\
(9.2)\end{array}$ & $\begin{array}{c}0.26 \\
(0.12-0.56)\end{array}$ & $<0.05$ & $\begin{array}{l}79 \\
(27)\end{array}$ & $\begin{array}{c}24 \\
(11)\end{array}$ & $\begin{array}{c}0.37 \\
(0.22-0.62)\end{array}$ & $<0.05$ \\
\hline $\begin{array}{l}\text { Hookworm } \\
\mathrm{n}(\%)\end{array}$ & $\begin{array}{c}4 \\
(5)\end{array}$ & - & $\begin{array}{c}0.00 \\
(0.00-2.73)\end{array}$ & 0.12 & $\begin{array}{c}22 \\
(25)\end{array}$ & - & $\begin{array}{c}0.00 \\
(0.00-0.28)\end{array}$ & $<0.05$ & $\begin{array}{c}40 \\
(26)\end{array}$ & $\begin{array}{c}2 \\
(1.7)\end{array}$ & $\begin{array}{c}0.05 \\
(0.01-0.21)\end{array}$ & $<0.05$ & $\begin{array}{c}66 \\
(21)\end{array}$ & $\begin{array}{c}2 \\
(0.9)\end{array}$ & $\begin{array}{c}0.03 \\
(0.01-0.15)\end{array}$ & $<0.05$ \\
\hline
\end{tabular}

Table 4

Comparison of intestinal protozoan infections frequencies in 2002 and 2004 in Santa Isabel do Rio Negro, Amazonas, Brazil

\begin{tabular}{|c|c|c|c|c|c|c|c|c|c|c|c|c|c|c|c|c|}
\hline \multirow{2}{*}{$\frac{\text { Age group (years) }}{\text { Parasite }}$} & \multicolumn{4}{|c|}{1 to 5} & \multicolumn{4}{|c|}{6 to 14} & \multicolumn{4}{|c|}{$>14$} & \multicolumn{4}{|c|}{ Total } \\
\hline & $\begin{array}{c}2002 \\
\mathrm{n}=71\end{array}$ & $\begin{array}{c}2004 \\
\mathrm{n}=40\end{array}$ & $\begin{array}{c}\text { OR } \\
95 \% \mathrm{CI}\end{array}$ & $\mathrm{p}$ & $\begin{array}{c}2002 \\
\mathrm{n}=86\end{array}$ & $\begin{array}{c}2004 \\
\mathrm{n}=54\end{array}$ & $\begin{array}{c}\text { OR } \\
95 \% \mathrm{CI}\end{array}$ & $\mathrm{p}$ & $\begin{array}{c}2002 \\
\mathrm{n}=151\end{array}$ & $\begin{array}{c}2004 \\
\mathrm{n}=119\end{array}$ & $\begin{array}{c}\text { OR } \\
95 \% \mathrm{CI}\end{array}$ & $\mathrm{p}$ & $\begin{array}{c}2002 \\
n=308\end{array}$ & $\begin{array}{c}2004 \\
n=213\end{array}$ & $\begin{array}{c}\mathrm{OR} \\
95 \% \mathrm{CI}\end{array}$ & $\mathrm{p}$ \\
\hline $\begin{array}{l}\text { Any protozoan } \\
\mathrm{n}(\%)\end{array}$ & $\begin{array}{c}33 \\
(46)\end{array}$ & $\begin{array}{c}10 \\
(25)\end{array}$ & $\begin{array}{c}0.38 \\
(0.15-0.97)\end{array}$ & $<0.05$ & $\begin{array}{c}49 \\
(57)\end{array}$ & $\begin{array}{c}23 \\
(43)\end{array}$ & $\begin{array}{c}0.56 \\
(0.27-1.18)\end{array}$ & 0.09 & $\begin{array}{l}104 \\
(69)\end{array}$ & $\begin{array}{c}42 \\
(35)\end{array}$ & $\begin{array}{c}0.25 \\
(0.14-0.42)\end{array}$ & $<0.05$ & $\begin{array}{l}189 \\
(61)\end{array}$ & $\begin{array}{l}75 \\
(35)\end{array}$ & $\begin{array}{c}0.34 \\
(0.23-0.50)\end{array}$ & $<0.05$ \\
\hline $\begin{array}{l}\text { Entamoeba histolytical } \\
\text { dispar } \\
\mathrm{n}(\%)\end{array}$ & $\begin{array}{l}12 \\
(17)\end{array}$ & $\begin{array}{c}5 \\
(13)\end{array}$ & $\begin{array}{c}0.70 \\
(0.20-2.40)\end{array}$ & 0.53 & $\begin{array}{l}29 \\
(34)\end{array}$ & $\begin{array}{c}6 \\
(11)\end{array}$ & $\begin{array}{c}0.25 \\
(0.08-0.69)\end{array}$ & $<0.05$ & $\begin{array}{l}64 \\
(42)\end{array}$ & $\begin{array}{l}18 \\
(15)\end{array}$ & $\begin{array}{c}0.11 \\
(0.06-0.22)\end{array}$ & $<0.05$ & $\begin{array}{l}105 \\
(34)\end{array}$ & $\begin{array}{l}29 \\
(14)\end{array}$ & $\begin{array}{c}0.30 \\
(0.19-0.49)\end{array}$ & $<0.05$ \\
\hline $\begin{array}{l}\text { Giardia lamblia } \\
\mathrm{n}(\%)\end{array}$ & $\begin{array}{c}15 \\
(21)\end{array}$ & $\begin{array}{c}4 \\
(10)\end{array}$ & $\begin{array}{c}0.41 \\
(0.11-1.49)\end{array}$ & 0.13 & $\begin{array}{c}7 \\
(8.1)\end{array}$ & $\begin{array}{c}3 \\
(5.5)\end{array}$ & $\begin{array}{c}0.66 \\
(0.13-3.04)\end{array}$ & 0.56 & $\begin{array}{c}5 \\
(3.3)\end{array}$ & $\begin{array}{c}6 \\
(5)\end{array}$ & $\begin{array}{c}1.55 \\
(0.41-6.03)\end{array}$ & 0.47 & $\begin{array}{c}27 \\
(8.8)\end{array}$ & $\begin{array}{c}13 \\
(6.1)\end{array}$ & $\begin{array}{c}0.68 \\
(0.32-1.40)\end{array}$ & 0.26 \\
\hline $\begin{array}{l}\text { Entamoeba coli } \\
\mathrm{n}(\%)\end{array}$ & $\begin{array}{c}13 \\
(18)\end{array}$ & $\begin{array}{c}4 \\
(10)\end{array}$ & $\begin{array}{c}0.50 \\
(0.12-1.81)\end{array}$ & 0.24 & $\begin{array}{l}30 \\
(35)\end{array}$ & $\begin{array}{c}11 \\
(20)\end{array}$ & $\begin{array}{c}0.48 \\
(0.20-1.13)\end{array}$ & 0.06 & $\begin{array}{c}73 \\
(48)\end{array}$ & $\begin{array}{c}19 \\
(16)\end{array}$ & $\begin{array}{c}0.20 \\
(0.11-0.38)\end{array}$ & $<0.05$ & $\begin{array}{l}116 \\
(38)\end{array}$ & $\begin{array}{c}37 \\
(17)\end{array}$ & $\begin{array}{c}0.35 \\
(0.22-0.54)\end{array}$ & $<0.05$ \\
\hline $\begin{array}{l}\text { Iodamoeba butschlii } \\
\mathrm{n}(\%)\end{array}$ & $\begin{array}{c}9 \\
(13)\end{array}$ & - & $\begin{array}{c}0.00 \\
(0.00-0.98)\end{array}$ & $<0.05$ & $\begin{array}{c}10 \\
(12)\end{array}$ & $\begin{array}{c}1 \\
(1.8)\end{array}$ & $\begin{array}{c}0.14 \\
(0.01-1.14)\end{array}$ & $<0.05$ & $\begin{array}{c}39 \\
(26)\end{array}$ & $\begin{array}{c}3 \\
(2.5)\end{array}$ & $\begin{array}{c}0.07 \\
(0.02-0.26)\end{array}$ & $<0.05$ & $\begin{array}{c}58 \\
(19)\end{array}$ & $\begin{array}{c}4 \\
(1.9)\end{array}$ & $\begin{array}{c}0.08 \\
(0.03-0.24)\end{array}$ & $<0.05$ \\
\hline
\end{tabular}




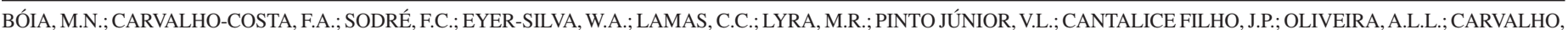

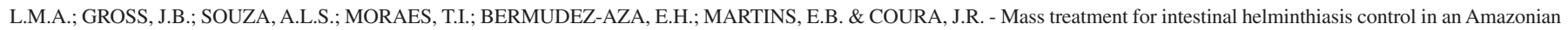
endemic area in Brazil. Rev. Inst. Med. trop. S. Paulo, 48(4): 189-195, 2006.

Table 5

Comparison of intestinal poliparasitism infections frequencies in 2002 and 2004 in Santa Isabel do Rio Negro, Amazonas, Brazil

\begin{tabular}{|c|c|c|c|c|}
\hline Parasites & $\begin{array}{c}2002 \\
(\mathrm{n}=308) \\
\mathrm{n}(\%)\end{array}$ & $\begin{array}{c}2004 \\
(\mathrm{n}=214) \\
\mathrm{n}(\%)\end{array}$ & $\mathrm{p}$ & $\mathrm{OR} / 95 \% \mathrm{IC}$ \\
\hline A. lumbricoides $+T$. trichiura & $36(12)$ & $11(5.1)$ & $<0.05$ & $0.38 / 0.18-0.81$ \\
\hline A. lumbricoides + hookworm & $22(7)$ & - & $<0.05$ & $0.06 / 0.00-0.58$ \\
\hline T. trichiura + hookworm & $8(2.5)$ & - & 0.06 & $0.18 / 0.01-1.41$ \\
\hline A. lumbricoides $+T$. trichiura + hookworm & $17(5.4)$ & $1(0.5)$ & $<0.05$ & $0.08 / 0.00-0.58$ \\
\hline Any helminth poliparasitism & $83(26)$ & $12(5.6)$ & $<0.05$ & $0.16 / 0.08-0.32$ \\
\hline Any helminth + Entamoeba histolytica/dispar & $70(22)$ & $14(6.5)$ & $<0.001$ & $0.24 / 0.13-0.46$ \\
\hline
\end{tabular}

determinants, as evidenced by the sanitary conditions of the municipality's seat, which showed a very unfavorable situation. It was demonstrated, in the first survey, that soil-transmitted helminth infections were more frequent in the worst socioeconomic and sanitary backgrounds. Frequencies of these infections were significally higher on dwellings without latrines and on families whose parents had no income. The different education and literacy rate of the families did not result in significant variation of prevalence of intestinal helminth infections, although there was a trend of lower infections in more educated families.

Rural emigration and urbanization in Amazon represents, in a small scale, demographic tendencies observed on more populated Brazilian regions. At studied region, people originated from riverine communities, isolated in forest, have been migrated to the municipality seat, being installed under low conditions. Dwelling characteristics are very unfavorable. Houses are made with wood and sometimes have no floor. Environmental contamination with soil-transmitted helminths infective forms is high. In this scenario, children are on great risk for acquisition of high worm burdens.

As recommended by WHO, we concur that there are three main clear interventions for the control of enteric parasitic diseases: periodic anti-helminthic treatment, improvements of sanitation and health education. These can be analyzed in a hierarchical structure, with short, middle and long dated measures, all needing sustainability of actions and acting in an interdependent framework. The strategy of mass administration of anti-helminthics may be seen as a practicable shortdated measure with low costs, capable to reduce the burden attributed to soil-transmitted helminthiasis, and to educate the population about the importance of those infections and the need of deworming. Periodical deworming possibly could be more sustainable and effective if addressed to high risk groups and people with high parasitic burdens. The concept of 'worming-person', in this context, cames from the recognition that school-aged children are responsible for most of environmental contamination with infective forms. Deworming actions could be attached to immunization campaigns. Also, participation of school teachers for antihelmintic administration should be considered.

Safe water supply and improved sanitation are other focal points for intervention in this area.

Systems for collection and disposal of human wastes are considered politically and economically unproductive and costs of these facilities are often assumed by families. In this context, the pit-privy should represent an improvement on quality of excreta disposal ${ }^{20}$. It consists of a hand-doug pit over which is placed a squatting plate or slab, riser and seat. The pit-privy is a minimum-cost solution providing for defecation, excreta storage, digestion of waste solids and seepage of urine and moisture into the surrounding soil ${ }^{20}$.

Cultural aspects may also influence improvement in practices of excreta disposal. The latrine program undertaken in Brazil during the early 1950s, which installed nearly two thousand latrines in rural villages of the Rio Doce valley is an example of such problem. Two years after its inauguration was discovered that few of the privies so installed were still in use and some had never been used ${ }^{28}$.

This reality points to the crucial importance of the third and probably most important target on enteric transmitted diseases control: health education. In societies where community health education is poor, sanitation demands are low because of the lack of awareness on the people about relationships between poor hygiene and disease. Health education is intrinsically linked to general and regular education. Illiteracy rate reaches about $17 \%$ in Santa Isabel do Rio Negro and near half of population has four or less study years. If health education messages are included in the school curricula, universal access to school will contribute to improve the comprehension about importance of soil-transmitted helminthiasis prevention. In a scenario of low access to school and high illiteracy rate, alternative health education programs should be implemented. In this context, education material should largely consists of posters with drawings and less of written messages. Public Health personnel working as health agents should be trained to educate people about hygiene and enteric parasitic diseases prevention.

This trial contributed to estimate the prevalence of enteric parasitic infections and the sanitary conditions in an urban area in Brazilian Amazon, and showed the role of a mass drug administration campaign as a practicable short-dated measure against soil-transmitted helminthiasis. Also, the study showed the need of improvement on sanitation and safe water supply in the locality. Additionally, a project of health education should be carried out by health and education personnel. Further studies with large samples, including riverine communities and assessing intensity of infections are needed to better evaluate the impact of such interventions. 


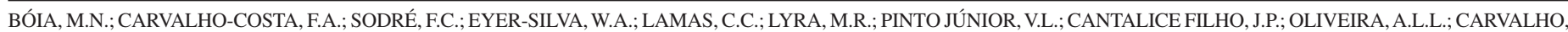
L.M.A.; GROSS, J.B.; SOUZA, A.L.S.; MORAES, T.I.; BERMUDEZ-AZA, E.H.; MARTINS, E.B. \& COURA, J.R. - Mass treatment for intestinal helminthiasis control in an Amazonian endemic area in Brazil. Rev. Inst. Med. trop. S. Paulo, 48(4): 189-195, 2006.

\section{ACKNOWLEDGEMENTS}

We give special thanks to the people of Santa Isabel do Rio Negro, who nicely received us in their homes, providing information and clinical samples; to the municipality's administrative staff for support on lodging the research team and to Mr. Tiago Carvalho-Costa for the English version of the manuscript.

\section{RESUMO}

\section{Tratamento em massa para controle das helmintíases intestinais em área endêmica na Amazônia Brasileira}

O presente trabalho objetivou avaliar a prevalência e o papel de um tratamento em massa das helmintíases intestinais em Santa Isabel do Rio Negro, Estado do Amazonas, Brasil. Foi realizado em 2002 um estudo seccional, incluindo inquérito copro-parasitológico, objetivando a obtenção das prevalências das parasitoses intestinais e dados sobre as condições sanitárias do local, estudando-se uma amostra de 308 indivíduos. Em 2003 foi realizada intervenção para tratamento em massa das helmintíases intestinais com administração de albendazol (ou mebendazol para crianças entre 12 e 24 meses) na sede do município, alcançando-se $83 \%$ de cobertura. Novo inquérito coproparasitológico foi realizado em 2004, para comparação das prevalências antes a após o tratamento. As prevalências das infecções por Ascaris lumbricoides, Trichuris trichiura e ancilostomídeos foram 48\%, 27\% e 21\%, respectivamente em 2002. Em 2004 observou-se redução significativa das infecções por Ascaris lumbricoides ( $\mathrm{p}<0,05$; OR / $95 \%$ IC $=0,44 / 0,30-0,65)$, Trichuris trichiura $(\mathrm{p}<0,05 ;$ OR $/ 95 \%$ $\mathrm{IC}=0,37 / 0,22-0,62)$, ancilostomídeos $(\mathrm{p}<0,05 ; \mathrm{OR} / 95 \%$ IC $=$ $0,03 / 0,01-0,15)$ e poliparasitismo por helmintos intestinais $(\mathrm{p}<$ 0,05; OR / 95\% IC = 0,16 / 0,08 - 0,32). Foi também observada redução da prevalência de infecção por Entamoeba histolytica/dispar ( $<<0,05$; $\mathrm{OR} / 95 \% \mathrm{CI}=0,30 / 0,19$ - 0,49). Concluiu-se que o tratamento em massa pode auxiliar o controle das helmintíases intestinais, porém ações governamentais em infraestrutura urbana e educação são essenciais para uma redução sustentada das prevalências destas infecções.

\section{REFERENCES}

1. ADMINISTRATIVE COMMITTEE ON COORDINATION/STANDING COMMITTEE ON NUTRITION - Fourth Report on the World Nutrition Situation. Geneva, ACC/SCN; IFPRI, 2000.

2. BRADLEY, M. \& HORTON, J. - Assessing the risk of benzimidazole therapy during pregnancy. Trans. roy. Soc. trop. Med. Hyg., 95: 72-73, 2001.

3. BUNDY, D.A.P. \& COOPER, E.S. - Trichuris and trichuriasis in humans. Advanc. Parasit., 28: 107-173, 1989.

4. BUNGIRO, R. \& CAPPELlO, M. - Hookworm infection: new developments and prospects for control. Curr. opin. infect. dis., 17: 421-426, 2004.

5. CHAN, M.S. - The global burden of intestinal nematode infections: fifty years on. Parasit. today, 13: 438-443, 1997.

6. COURA, J.R. \& AMARAL, R.S. - Epidemiological and control aspects of schistosomiasis in Brazilian endemic areas. Mem. Inst. Oswaldo Cruz, 99 (suppl. 1): 13-19, 2004.

7. CROMPTON, D.W.T.; NESHEIN, M.C. \& PAWLOWSKI, Z.S. - Ascariasis and its public health significance. London, Taylor \& Francis, 1985.
8. DE SILVA, N.R.; GUYATT, H. L. \& BUNDY, D.A.P. - Morbidity and mortality due to Ascaris-induced intestinal obstruction. Trans. roy. Soc. trop. Med. Hyg., 91: 3136, 1997.

9. DE SILVA, N.R.; SIRISENA, J.L.; GUNASEKERA, D.P.; ISMAIL, M.M. \& DE SILVA, H.J. - Effect of mebendazole therapy during pregnancy on birth outcome. Lancet, 353: 1145-1149, 1999.

10. DE SILVA, N.R.; BROOKER, S.; HOTEZ, P.J. et al. - Soil-transmitted helminth infections: updating the global picture. Trends Parasit., 19: 547-551, 2003.

11. FALLAH, M.; MIRAMAB, A.; JAMALIAN, F. \& GHADERI, A. - Evaluation of two years of mass chemotherapy against ascariasis in Hamadan, Islamic Republic of Iran. Bull. Wld Hith Org., 80: 399-402, 2002.

12. GELTMAN, P.L.; COCHRAN, J. \& HEDGECOCK, C. - Intestinal parasites among African refugees resettled in Massachusetts and the impact of an overseas predeparture treatment program. Amer. J. trop. Med. Hyg., 69: 657-662, 2003.

13. GUYATT, H.L. \& BUNDY D.A. - Estimating prevalence of community morbidity due to intestinal helminths: prevalence of infection as an indicator of the prevalence of disease. Trans. roy. Soc. trop. Med. Hyg., 85: 778-782, 1991.

14. GYORKOS, T.W. - Monitoring and evaluation of large scale helminth control programmes. Acta trop., 86: 275-282, 2003.

15. HADJU, V.; ABADI, K.; STEPHENSON, L.S. et al. - Intestinal helminthiasis, nutritional status, and their relationship; a cross-sectional survey in urban slum school children in Indonesia. Southeast Asian J. trop. Med. publ. Hlth, 26: 719-729, 1995.

16. INSTITUTO BRASILEIRO DE GEOGRAFIA E ESTATÍSTICA - Sinopse preliminar do censo demográfico de 2000 - Malha municipal digital do Brasil, 1997. Brasilia, IBGE, 2002. http://www.ibge.gov.br/cidadesat/default.php2000 (16/11/2003).

17. JUNK, W.J. - As águas da região amazônica. In: SALATI, E.; SHUBART, H.O.R.; JUNK, W. \& OLIVEIRA, A.E. Amazônia: desenvolvimento, integração e ecologia. São Paulo, Brasiliense; CNPq, 1983. p. 45-53.

18. KATZ, N. - Schistosomiasis control in Brazil. Mem. Inst. Oswaldo Cruz, 93 (suppl. 1): 33-35, 1998.

19. LACEY, E. - Mode of action of benzimidazoles. Parasit. today, 6: 112-115, 1990.

20. McGARRY, M.G. - Waste collection in hot climates: a technical and economical appraisal. In: FEACHEM, R.; McGARRY, M. G. \& MARA, D. Water, wastes and health in hot climates. Chichester, John Wiley, 1977. p. 239-263.

21. MONTRESOR, A.; STOLZFUS, R.J.; ALBONICO, M. et al. - Is the exclusion of children under 24 months from anthelmintic treatment justifiable? Trans. roy. Soc. trop. Med. Hyg., 96: 197-199, 2002.

22. MONTRESOR, A.; AWASTHI, S. \& CROMPTON, D.W.T. - Use of benzimidazoles in children younger than 24 months for the treatment of soil-transmitted helminthiasis. Acta trop., 86: 223-232, 2003.

23. NARAIN, K.; MEDHI, G.K.; RAJGURU, S.K. \& MAHANTA, J. - Cure and reinfection patterns of geohelminthic infections after treatment in communities inhabiting the tropical rainforest of Assam, India. Southeast Asian J. trop. Med. publ. Hlth, 35: 512-517, 2004.

24. OBERHELMAN, R.A.; GUERRERO, E.S.; FERNANDEZ, M.L. et al. - Correlations between intestinal parasitosis, physical growth, and psychomotor development among infants and children from rural Nicaragua. Amer. J. trop. Med. Hyg., 58: 470-475, 1998.

25. OLNESS, K. - Effects on brain development leading to cognitive impairment: a worldwide epidemic. J. dev. behav. Pediat., 24: 120-130, 2003.

26. ORDONEZ, L.E. \& ANGULO, E.S. - Malnutrition and its association with intestinal parasitism among children from a village in the Colombian Amazonian region. Biomedica, 22: 486-498, 2002. 


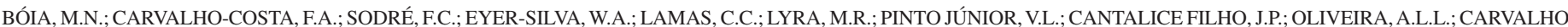
L.M.A.; GROSS, J.B.; SOUZA, A.L.S.; MORAES, T.I.; BERMUDEZ-AZA, E.H.; MARTINS, E.B. \& COURA, J.R. - Mass treatment for intestinal helminthiasis control in an Amazonian endemic area in Brazil. Rev. Inst. Med. trop. S. Paulo, 48(4): 189-195, 2006.

27. QUIHUI-COTA, L.; VALENCIA, M.E.; CROMPTON, D.W.T. et al. - Prevalence and intensity of intestinal parasitic infections in relation to nutritional status in Mexican schoolchildren. Trans. roy. Soc. trop. Med. Hyg., 98: 653-659, 2004.

28. SANCHES, W.R. \& WAGNER, E.G. - Experience with excreta-disposal programmes in rural areas of Brazil. Bull. Wld Hlth Org., 10: 229-249, 1954.

29. SHUBAIR, M.E.; YASSIN, M.M.; AL-HINDI, A.I. et al. - Intestinal parasites in relation to haemoglobin level and nutritional status of school children in Gaza. J. Egypt. Soc. Parasit., 30: 365-375, 2000.

30. STEPHENSON, L.S.; LATHAM, M.C. \& OTTESEN, E.A. - Malnutrition and parasitic helminth infections. Parasitology 121 (suppl.): S223-S238, 2000.

31. SUR, D.; SAHA, D.R.; MANNA, B.; RAJENDRAN, K. \& BHATTACHARYA, S.K. Periodic deworming with albendazole and its impact on growth status and diarrhoeal incidence among children in an urban slum of India. Trans. roy. Soc. trop. Med. Hyg., 99: 261-267, 2005.

32. URBANI, C. \& ALBONICO, A. - Anthelmintic drug safety and drug administration in the control of soil-transmitted helminthiasis in community campaigns. Acta trop., 86: $215-221,2003$.

33. VAN DEN BOSSCHE, H.; ROCHETTE, F. \& HORIG, C. - Mebendazole and related antihelmintics. Advanc. Pharmacol. Chemother., 19: 67-128, 1982.
34. WORLD BANK - World development report 1993. Investing in health. Oxford, University Press, 1993.

35. WORLD HEALTH ORGANIZATION - Report of the WHO informal consultation on hookworm infection and anaemia in girls and women. Division of control of tropical diseases. Geneva, WHO, 1996. (WHO/CDT/SIP.96.1.).

36. WORLD HEALTH ORGANIZATION - Control of of schistosomiasis and soiltransmitted helminth infections. Report by secretariat. 27 October 2000. Division of communicable diseases. Geneva, WHO, 1996. (EB107/31).

37. WORLD HEALTH ORGANIZATION - Prevention and control of schistosomiasis and soil-transmitted helminthiasis. Wld Hlth Org. techn. Rep. Ser., (912), 2005.

38. WORLD HEALTH ORGANIZATION - Prevention and control of schistosomiasis and soil-transmitted helminths. Geneva, WHO; UNICEF, 2004. http:// whqlibdoc.who.int/hq/2004, 2004.

39. YOUNG, K.H.; BULLOCK, S.L.; MELVIN, D.M. \& SPRUILL, C.L. - Ethyl acetate as a substitute for diethyl ether in the formalin-ether sedimentation technique. J. clin. Microbiol., 10: 852-853, 1970.

Received: 4 November 2005

Accepted: 13 April 2006 